\title{
Do Transformational Leadership, Interpersonal Communication, and Career Development Have Direct and Indirect Effect on Diplomats' Organizational Commitment at the Ministry of Foreign Affairs Republic of Indonesia in Jakarta?
}

\author{
Asrarudin \\ Universitas Negeri Jakarta \\ Email: asrarudin_im15s3@mahasiswa.unj.ac.id \\ Dedi Purwana \\ Universitas Negeri Jakarta \\ Email: dpurwana@unj.ac.id \\ R. Madhakomala \\ Universitas Negeri Jakarta \\ Email: madhakomala@unj.ac.id
}

\begin{abstract}
Objective of this research is to determine direct and indirect effects of transformational leadership, interpersonal communication, and career development on the commitment of diplomats at the Ministry of Foreign Affairs of the Republic of Indonesia in Jakarta. The sample design used is probability sampling which provides equal opportunity for each element (member) of the population to be selected as a sample member. And the technique for determining the number of samples is proportionate Stratified Random Sampling. This technique is used because the population is not homogeneous and proportionally distributed.

The research design used is a quantitative approach with a total sample of 255 respondents. The data analysis tool used is Structural Equation Modeling (SEM) with WarpPLS 5.0 software. This research reveals that transformational leadership has a positive and significant effect on interpersonal communication which indicates that the better transformational leadership, interpersonal communication will be more increased; transformational leadership has a positive and significant influence on career development which describes that the better transformational leadership, career development will get better; Transformational leadership contributes positively and significantly to organizational commitment through career development which shows an increase in career development then transformation leadership will be better and have an impact on increasing organizational commitment; and interpersonal communication has a positive but not significant role on organizational commitment through career development which shows that good interpersonal communication has neither effect on career development nor impact on the commitment of diplomatic organizations in the Ministry of Foreign Affairs of the Republic of Indonesia.
\end{abstract}

Keywords: Transformational leadership, interpersonal communication, career development, organizational commitment

Received: 10 January 2020 ;

Accepted: 16 January 2020 ;

Publish; June 2020. 


\section{How to Cite:}

Asrarudin., Purwana, D., \& Madhakomala, R. (2020). Do Transformational Leadership, Interpersonal Communication, and Career Development Have Direct and Indirect Effect on Diplomats' Organizational Commitment at the Ministry of Foreign Affairs Republic of Indonesia in Jakarta?. International Journal of Human Capital Management, 4 (1), 59-73. https://doi.org/10.21009/IJHCM.04.01.05

\section{INTRODUCTION}

Environment and organization have a reciprocal influence that can contribute to changes and sustainability. In this case, leaders or managers strive effectively and efficiently to be able to adjust organizational development with dynamic environmental changes, and at the same time leaders are also faced with the challenge of how to manage resources of the organization with several strategies and approaches, especially human resources in order to achieve the goals and the mission of the organization.

Indonesia has a very strategic position and role both in the regional region and internationally. This strategic position is an important asset in implementing diplomacy in international forums. This strategic asset can be utilized as much as possible for the national interest. The optimal use of the role of diplomacy in international relations is oriented towards achieving national interests. Therefore, the role and leadership of Indonesia in ASEAN regional cooperation, in maintaining world peace, south-south cooperation, improving the quality of protection of Indonesian citizens abroad, and promoting human rights and democracy is very crucial (Strategic Plan of the Ministry of Foreign Affairs (Renstra Kemenlu 2015 - 2019; 13 ).

Some strategic efforts are taken to optimize the role and position of Indonesia both in the regional or in international level, the ability and competence of leadership and human resources (diplomats) need to be continuously improved. Therefore, the Ministry of Foreign Affairs of the Republic of Indonesia has a serious commitment to improve competency based and transparent performance management.

Efforts to improve leadership competence and the quality of human resources (diplomats) cannot be separated from the development of information and communication technology. The mastery and use of information and communication technology can no longer be avoided in increasing the capacity of the role of diplomacy, as stated by the Director General of Information and Public Diplomacy at the Regional Conference on Digital Diplomacy (RCDD), 10 September 2019) that the Ministry of Foreign Affairs is committed to increasing capacity in the utilization of digital technology for the implementation of diplomacy consistently and continuously. Optimal use of digital technology in an effort to achieve digital diplomacy is improved sustainably.

Based on the above statements, the Ministry of Foreign Affairs R.I actually the competencies and capabilities of human resources (diplomats) still need to be developed consistently to enhance the optimization of the active role of diplomacy. This is in line with the research findings conducted by Fitriani and Vido Chandra Panduwinata (2015-2018) that the Ministry of Foreign Affairs R.I still suffers from lack of adequate human resources to deal with very complicated cases. This finding is reinforced by the SWOT Analysis in the Ministry of Foreign Affairs Strategic Plan (2015-2019: 21) as follows: (1) HR placement is not in accordance with the competency; (2) organization management system and good performance is not yet well-performed; (3) facilities and infrastructure is not yet supporting, especially IT; and (4) inadequate internal regulation.

Based on the findings of preliminary research and various statements on leadership commitment, the competence and capability of human resources (diplomats) should be improved consistently and sustainably. Developing human resources at the Ministry of Foreign Affairs of the Republic of Indonesia is conducted through education and training. There are three (3) levels of education and training at the Ministry of Foreign Affairs of the Republic of Indonesia: (1) Junior Diplomatic Training Course (SEKDILU) for 8 months as the basic level of diplomatic and consular training aimed at forming professional and intelligent Junior Diplomats (diplomat pratama), possessing personality and laudable behavior, high morale to carry out diplomatic and consular duties; (2) Mid-Career Diplomatic Training Course (SESDILU) for 4 months for an intermediate level diplomatic and consular training and training program aimed at forming 
professional and intelligent Mid-Career Diplomats (diplomat Madya), possessing excellent personality and behavior, possessing analytical skills and more reliable diplomacy skills and leadership; (3) Senior Diplomatic Training Course (SESPARLU) for 4 months is diplomatic and consular education and training at the Main level whose aim is to establish Senior Diplomats (diplomat Utama) who has personality and commendable behavior, a high fighting spirit, able to formulate programs and policies, proficient in diplomacy, has sharp analytical skills, able to formulate ideas or recommendations for solving national, regional and international problems, and has good leadership in carrying out political activities and foreign relations.

Efforts to strengthen HR must be carried out consistently and continuously in the efforts to achieve the vision and mission of the Ministry of Foreign Affairs of the Republic of Indonesia as stated in the Ministry of Foreign Affairs Strategic Plan (2015 - 2019; 23) as follows:

\section{Vision:}

Materializing diplomacy authority to strengthen national identity as a maritime nation for the benefit of the people.

\section{Missions:}

1. Strengthening the role and leadership of Indonesia as a maritime country in international cooperation to promote national interests;

2. Strengthening the role of the Ministry of Foreign Affairs as the executive of foreign relations with the support and active role of all national stakeholders;

3. Realizing the capacity of the Indonesian Ministry of Foreign Affairs and qualified and accountable representatives (Ministry of Foreign Affairs Strategic Plan 2015-2019; 52).

The Ministry of Foreign Affairs is committed to improving the quality of performance planning and performance alignment, improving performance indicators and determining performance targets, conducting periodically performance evaluations, implementing reward and punishment, and increasing HR capacity (Ministry of Foreign Affairs Strategic Plan 2015-2019; 13). Thus, human resources (diplomats) are the most strategic organizational resources as stated by Soudabeh Vatankhah, Samira Alirezaei, Omid Khosravizadeh, Seyyed Elmira Mirbahaeddin, Mahtab Alikhani, Mobarakeh Alipanah $(2017$; 4979) that human resources are the most strategic organizational resources, has a significant role in producing organizational outcomes, both government and business organizations.

As explained at the outset, one of Indonesia's national interests is to protect the interests of Indonesian citizens abroad through the optimal role of diplomacy. The services and protection of Indonesian citizens abroad still require serious attention through Indonesian diplomacy, as stated by the Minister of Foreign Affairs of the Republic of Indonesia (Jakarta, 2019) that the Ministry of Foreign Affairs is committed to improving the service and protection system of Indonesian citizens abroad. Stated that Indonesian government through Ministry of Foreign Affairs must continue to improve public services and protection of Indonesian citizens, and the challenges of the government in providing public services and protection of Indonesian citizens abroad will be even greater. On another occasion the Indonesian Minister of Foreign Affairs (2015) suggested that Indonesia's diplomacy and foreign policy must be able to provide protection and security for Indonesian citizens and legal entities abroad.

These two statements show that the presence of the Indonesian government through the Ministry of Foreign Affairs to provide services and protection for the interests of Indonesian citizens abroad is still becoming national problem that requires serious commitment to be increased. The Ministry of Foreign Affairs together with various Indonesian Representatives abroad has handled as many as 16,184 cases, of which 11,804 cases have been successfully resolved and 4,380 cases are still being completed (Strategic Plan of the Ministry of Foreign Affairs in 2015 - 2019; 11).

Transforming human resources effectively and continuously should be strategic policies to improve organizational performance and competitiveness. In this context, psychological characteristics such as trust, recognition, mutual respect and attitude are very important elements for organizational growth and sustainability. For this reason, the type of leadership in managing the psychological characteristics of human resources in an organization principally can determine organizational change. Transformation of human resource management concept indicating the strategic integration of the leadership model. In this reason, the management of the human element in the organization becomes more productive to improve organizational performance, both government organizations and public or government organizations. In this context, leaders in government organizations strive continuously to improve the quality of 
human resource management, innovating public services and efficiency that provides socioeconomic impacts for the advancement of a region, as Dingxiang Chen, Xiaobao Peng said as that government departments continue to improve the level of management and service innovation, not only conducive to efficient and smooth operation of the department, but also having an important impact on the economic and social development of the region as a whole. $(2017 ; 82)$.

One of the leadership styles that is currently widely studied, debated and developed in various management literatures is the transformational leadership style. The concept of transformational leadership is a leadership theory that encompasses many aspects, developed by Bass in 1990 and subsequently reviewed by Avolio in 1999 and 2004 and further studied by Antonakis. According to Bass, transformational leaders are leaders who actively change the concept of individual or subordinate values in order to be able to think and behave not only for their own interests but also for the interests of groups and organizations (Deepika Dabke, 2016; 29).

In addition to transformational leadership, another important factor related to human resource management is interpersonal communication skills. Communication within an organization is an activity that determines the effectiveness of the achievement of organizational goals and values. Sengupta, written by Reeta Raina and Deborah Britt Roebuck (2016: 98), found that technological factors cause many changes in communication activities in organizations, but effective and sustainable communication at all levels of the organization never changes. Thus, communication from the bottom up (upward communication), communication from the top down (downward communication) and lateral communication (lateral communication) has a very important role to increase the commitment and competitiveness of an organization, as stated Botero \& Van Dyne written by Reeta Raina and Deborah Brit Roebuck $(2016$; 98) that continuous and ongoing communication from leaders, managers, and employees can help abating the uncertainty and concerns of the people affected.

As described above, transformational leadership and interpersonal communication skills play an important role in achieving individual success in an organization, as well as career development. Careers can be defined as patterns or sequences of the roles of a person's work. Traditionally the word "career" is intended as someone who has a managerial position and professional role, but now the word "career" can be intended for everyone in the organization according to the work role. Careers can also be conceptualized more broadly in terms of individual development in learning and work throughout his/her life.

Many writers/researches have given a very dramatic picture of career development. Traditional careers in an organization are characterized by career development according to an organizational hierarchy that is managed based on career plans. According to Derek Torrington, Laura Hall, and Stephen Taylor (2005: 408) career development based on organizational hierarchy is actually no longer sufficient in today's digital era. The current organizational structure is flatter, more flexible, liquid and cost-effective to deal with an uncertain and unpredictable future. With such an organizational structure, the organization no longer provides long-term career development to build employee loyalty, commitment and performance.

The long-term sustainability of an organization, whether government institution or business one is partly due to the strong commitment and consistency of employees towards achievement the organizational goals and values. Organizational commitment has a very strategic role for productivity, efficiency and effectiveness of conducting work for the survival of the organization. Employees' commitment to the organization can be loyalty, care, trust, and long-term consistent support for the achievement of the goals and values of the organization. Organizational commitment, job satisfaction, customer satisfaction and product quality are intangible concepts that have an influence on organizational performance, as explained by Kaplan and Norton, as quoted by Victoria Miroshnik (2013: 28) that corporate performance should include both tangible and intangible concepts. Tangible factors of CP are sales, production, profits, return to assets, return to investments, market share, and so forth. Intangible factors of $\mathrm{CP}$ are job satisfaction, customer satisfaction, organizational commitment, product quality, and so forth. 


\section{Transformational Leadership and Interpersonal Communication}

Transformational leadership is a leader who has ability to internalize the cultural values of the organization to all people in the organization with the aim of establishing partnerships that provide mutual benefits in a consistent and sustainable manner. Transformative leaders always provide motivation and inspiration and encourage their subordinates to directly or indirectly participate in the decision making process. Sajeet Pradhan and Rabindra Kumar Pradhan (2015: 228) explained that transformational leadership (TL) is refreshingly different from all previous leadership theories in a way that it empowers or enables the followers. The leader engages with followers in a way where both the leader and the follower transcend to a higher level of motivation and morality. Melvyn R. W. Hamstra, Nico W. Van Yperen, Barbara Wisse, and Kai Sassenberg (2014: 415) stated that Transformational leaders exert influence on their followers by communicating an idealistic vision of the future. Moreover, they recognize followers' individual needs and abilities and stimulate their intellectual development; and Torrington et al., (2005;308) defined transformational leadership, which focuses on the leader's role at a strategic level, so there is a concentration on the one leader at the top of the organization.

Based on the concepts above, transformational leadership has a very important and strategic position in making fundamental changes and broad impacts for the government organizations or business ones. The success of transformative change is largely determined by the active role and consistency of the attitudes and behaviors of transformational leadership.

Transformational leadership is related to interpersonal communication as stated by Sahin G., et al., $(2016 ; 4)$ that the success and efficiency of work leaders are not only based on the nature or attitude they have, but the behavioral factors shown in their leadership have very important role. One of the important behaviors in leadership is communication skills, both communicating among leaders and leaders with subordinates. And also Qader Vazifeh Damirch, Gholamreza Rahimi, and Mir Hosein Seyyedi (2011: 121) suggest the relationship of transformational leadership with interpersonal communication. They explained that Transformational leadership also involves offering support and encouragement to individual followers. In order to foster supportive relationships, transformational leaders keep lines of communication open so that followers feel free to share ideas and so that leaders can offer direct recognition of each follower's unique contributions.

\section{Transformational Leadership and Career Development}

Leadership is the interaction of mutual effect between leaders and subordinates or subordinate and groups to create change in an effort to achieve individual and organizational goals. Therefore, the concept of leadership in essence provides change for individuals and organizations through processes and interactions. The concept of leadership has evolved and many management experts researched about leadership and introducing various concepts of leadership, including transformational leadership.

Piccolo, Colquitt, and Yukl, quoted by Xueli Wang, Lin Ma, and Mian Zhang (2016: 26) suggested that transformational leadership provides constructive feedback, encourages subordinates to work harder and think creatively to solve problems that arise, and form commitments towards achieving organizational goals, values and strategies. Mehmet Sahin G and Büşra K. $(2016 ; 1)$ explain that leadership behavior (transformational leadership) influences career development. It is further explained that leadership," definition and roles of the manager, managerial levels and skills, efficient leadership, reflections of leadership and leadership theories in terms of the current entities affect job satisfaction and organizational commitment directly. job satisfaction means that as long as individuals are happy and peaceful in their job, the positive feeling they have towards their job increases.

Transformational leadership can influence career development ( Bass et al., 2006; 109). Further, Bass et all., state that there are three ways transformational leadership supports the career development of employees in an organization. First, transformational leadership shows itself as a role model to be emulated by subordinates. In this context, transformative leaders provide examples of good and productive attitudes and behaviors that are consistent and sustainable in accordance with organizational values. Second, transformative leaders always provide motivation and inspiration to subordinates to achieve better performance, both soft performance, such as loyalty, discipline, commitment, satisfaction, cooperation and hard performance, such as achievement on target and productivity. Third, organizational culture has a 
strategic role to support employee career developers. Not only that, organizational culture also has a role in running and maintaining employee career paths.

\section{Transformational Leadership and Organizational Commitment through Career Development}

Productivity and transformation of human resources are an important concern for organizational leaders. For each effective change in an organization produces outputs and outcomes as a measure of performance. In this context, beliefs, incentives, social interactions and individual attitudes become essential elements. For this reason, leadership becomes a decisive role in changing and directing employee attitudes, ways of thinking, interactions and motivation. One model of leadership that emphasizes behavioral management is transformational leadership (transformed leadership or TL).

Gabbar HA, Honarmand N. and Abdelsalam AA (2014: 7) describe the role of transformational leadership that with the power of vision and personality, transformational leaders are able to inspire subordinates to change expectations, perceptions and work motivation to achieve common goals. The relationship between transformational leaders and subordinates is based on the 'take and give' relationship. Personality and behavior of transformational leaders become 'role models' for subordinates, through this way change can be achieved.

The opinion of HA et al., above can be explained further that transformational leadership has the role of establishing the relationship of leaders with subordinates through strengthening vision and personality. In this context, transformational leadership is able to inspire subordinates through a two-way communication process to change expectations, perceptions and motivations in the effort to achieve organizational goals and values. The relationship between leaders and subordinates is not based on transactional but rather on personality, character, role models and the ability to make changes through role model, the ability to convey the organization's vision and mission. Therefore, the success of transformational leadership is consistent attitudes and behaviors that serve as role models for subordinates, and the main goal to be achieved is the interests of the group / team, organization or community.

Organizational commitment is an individual or employee bond with the organization on the basis of economic and non-economic motives. The relationship or bond of an individual with an organization with economic considerations means that the individual or employee does not want to leave his job because of consideration of salary / benefits received, long years of work, no other alternative work, and employment status. Whereas the relationship or bond of an individual with an organization with non-economic considerations means that the individual or employee does not wish to leave his job because of mutual trust, recognition, mutual respect within the organization which creates the convenience of interacting and working. Both economic and non-economic considerations gradually shape organizational commitment for over a long period.

\section{Interpersonal Communication and Organizational Commitment through Career Development}

Ole Boe and Torill Holth $(2017 ; 2)$ explain that communication is the main potential for leadership. Leaders must respond effectively to managing employee emotions and influences in positive ways. Leaders must be able to manage and explore the potentials of all human elements in the organization in an effort to achieve common goals. In this context, the leader must really understand the individual needs of all employees and adjust them to organizational goals in such a way to establish solidarity and strong commitment to the achievement of the goals and values of the organization. Relationships between leaders and subordinates on moral and ethical basis, mutual trust and respect will create a passionate and effective work team which principally forms a positive work atmosphere. Such a harmonious work environment indicates the leader is able to instill optimism through social interaction for the future progress of the organization, giving a positive influence on employee performance and organizational performance.

Bass and Avolio quoted by Ying Ao (2016: 102) explain that transformational leadership is an effective leadership model because it is able to transform attitudes, beliefs and ethical and moral values to building employee motivation. It is elaborated that Transformational leadership which includes the well-known four leadership aspects: idealized influence, inspirational motivation, intellectual stimulation and individualized consideration, is an effective and ideal 
leadership style since it emphasizes the process that leaders influence followers by transforming their attitudes, beliefs and values to facilitate their motivation.

Bass, B M. quoted by Mahmoud Kamal Abouraia and Saad Mohammed Othman (2017; 411) revealed that transformational leadership is related to organizational commitment mediated by job satisfaction. It is explained that a healthy relationship between leadership styles, values and standards at job satisfaction, motivation, performance and organizational commitment. There are numerous managerial techniques which might have an impact on staff members' job satisfaction, and their organizational commitment however one must necessarily acknowledge thereby is transformational leadership.

Sabghatullah G $(2018 ; 2)$ explains that establishing a strong and harmonious relationship between human elements in an organization is the main factor to achieve the goals and values of the organization. To be able to achieve these goals, the organization through the leadership of the organization must openly conduct day-to-day social interactions with subordinates. In this context, the leader also understands that not all subordinates have good communication skills, organizations are obliged to develop subordinate communication skills through training programs. The leader's social interaction with subordinates basically not only forms commitment and a stable work environment but also enhances overall organizational performance. Torrington et al., (2014; 338) then explained that two-way communication that occurred in formal communication indicates employee commitment to the organization.

\section{RESEARCH METHOD}

\section{Population and sample}

Sugiyono (2009: 8) explains that quantitative research methods are research methods based on positivism philosophy, used to examine specific populations or samples, data collection using research instruments, quantitative / statistical data analysis with the aim of testing established hypotheses. For this reason, the method used in this study is a quantitative method. because this research examines the relationship between variables (causal relationships). In addition, this study also aims to test the hypothesis of a positive and significant relationship between variables.

The sample design used in this study is sampling probability, which provides equal opportunities for each element (member) of the population to be selected as sample members. And the technique used to determine the number of samples is Proportionate Stratified Random Sampling (balanced representation technique). This balanced representation technique is used if the population has members / elements that are not homogeneous and proportionally distributed (Sugyono, 2009; 82). With accessible population of 957 and an error rate of $5 \%(0.05)$, the sample size is 255 (Sugyono, 2009; 87)

\section{Data Collection Techniques}

One method of data collection is by distributing questionnaires to predetermined respondents. Moh. Nazir (2009: 204) explains that the questionnaire with questions about opinions is a question to measure the "strength" of respondents' opinions about something ask or asses the attitude of respondents. For this reason, an analysis needs to be carried out to scoring and bring together the opinions and attitudes of the respondents.

\section{Data Analysis Method}

The causal relationship formulated in this study uses Structural Equation Modelling to explain the relationship of variables. This study uses a Partial Least Square (PLS) analysis tool with WarpPLS 5.0 software.

\section{Hypothesis Testing}

Analysis of the path coefficient is conducted by analyzing the significance of the size of regression weight. This analysis is done to show overall effect, direct and indirect effect of one variable with other variables (Wati, 2018). The formulation of the hypothesis of the amount of regression weight is as follows:

Ho $=\beta_{1} \leq 0$, indicates that there is no significant positive influence between the independent variables on the dependent variable 
$\mathrm{Ha}=\beta_{1}{ }^{1}>0$, indicates that there is a positive and significant influence between the independent variables on the dependent variable

The decision accept or reject the proposed hypothesis is made with the following conditions:

If $\mathbf{t}_{\text {statistics }}>\mathbf{t}_{\text {table }}$ or $\mathrm{P}_{\text {Value }}<0.05$, the null hypothesis (Ho) is rejected or Ha is accepted, meaning that statistically there is an influence between the two variables.

If $\mathbf{t}_{\text {statistics }}<\mathbf{t}_{\text {table }}$ or $\mathrm{P}_{\text {Value }}>0.05$, the null hypothesis (Ho) is accepted or Ha is rejected, meaning that statistically there is no influence between the two variables.

\section{Structural Equation Model}

Data analysis in this study uses a second order confirmatory based on the repeated indicator approach or commonly known as the hierarchical component model. Based on the research variables, dimensions and research indicators, then uses Structural Equation Model (SEM) for data analysis purposes. The Structural Equation Model is depicted in the following figure:

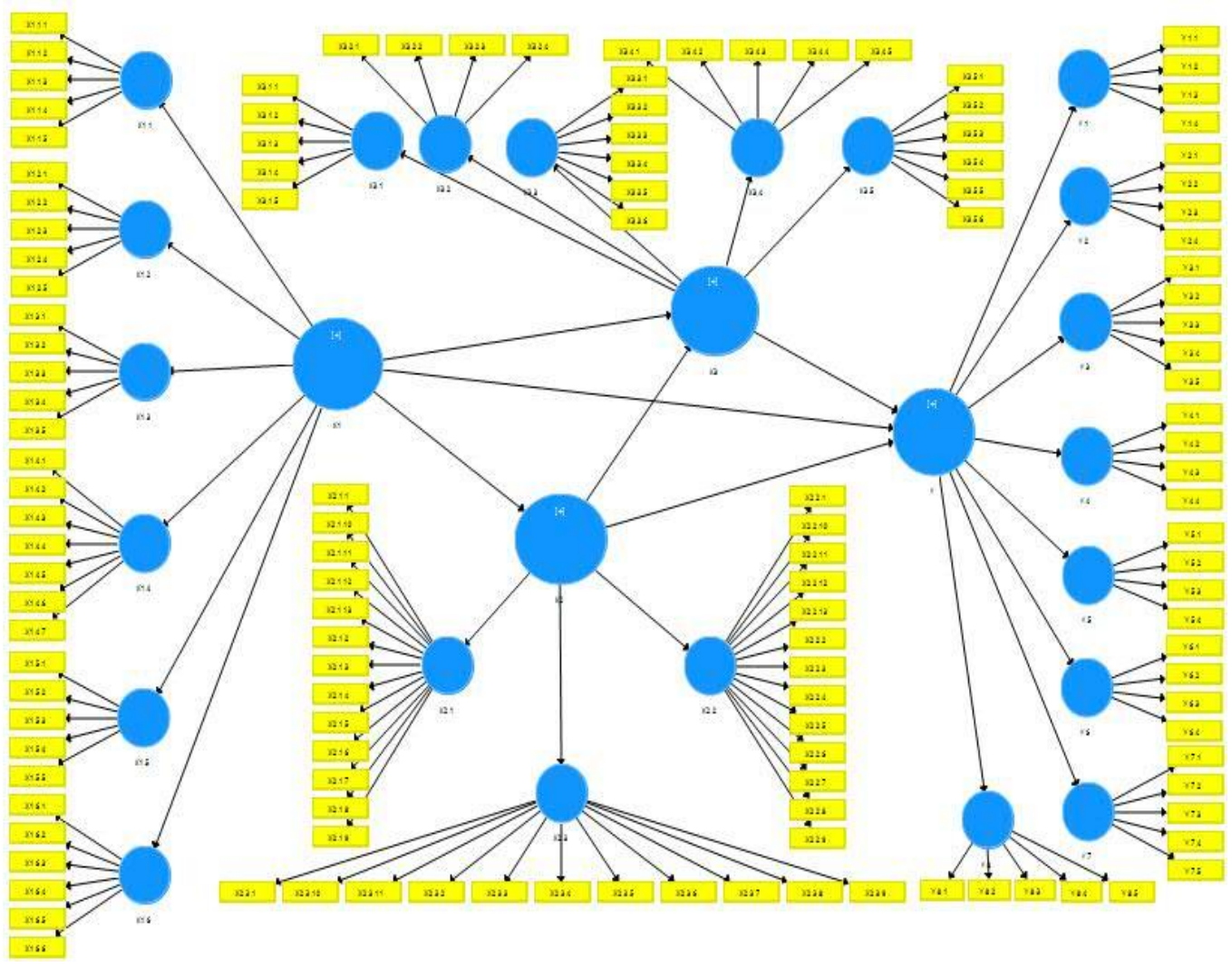

Based on the structural model, it can be explained that transformational leadership variable is measured with 6 dimensions, namely the ability to set an example, encourage diplomats to think creatively, receive input from subordinates, inspire subordinates, the ability to motivate subordinates, and the ability to build diplomatic commitments that are operationalized with 33 question items (indicators); Interpersonal communication variable is measured in 3 dimensions, namely communication between diplomats, communication between leaders and subordinates, communication between leaders which is operationalized with 37 questions (indicators); Career development variable is measured with 5 dimensions, namely knowledge, skills, abilities, attitudes and experiences that are operationalized with 26 questions (indicators); organizational commitment variable is measured with 8 dimensions, namely organizational value, trust, loyalty, career path, salary, employment status, job satisfaction and integrity that are operationalized with 35 questions (indicators). Thus, this study consists of 4 variables; 22 dimensions and 121 questions (indicators). 
This part are the result and findings based on the information and data found during this research conducted and analyzed using Partial Least Square (PLS) analysis tool with WarpPLS 5.0 software.

\section{Respondent Profiles}

Following is the profile of 225 respondents: Based on the criteria of respondents used as research subjects according to sex can be seen in the following table:

\begin{tabular}{ccccccc}
\hline \multirow{2}{*}{$\begin{array}{c}\text { Diplomatic } \\
\text { Rank }\end{array}$} & Men & $\%$ & Women & $\%$ & \multirow{2}{*}{ Total } & \multirow{2}{*}{$\%$} \\
\cline { 2 - 5 } & 19 & 59,37 & 13 & 40,63 & 32 & 100 \\
\hline Attache & 21 & 67,74 & 10 & 32,26 & 31 & 100 \\
\hline Secretary III & 48 & 63,16 & 28 & 36,84 & 76 & 100 \\
\hline Secretary II & 19 & 61,30 & 12 & 38,70 & 31 & 100 \\
\hline Secretary I & 29 & 65,91 & 15 & 34,09 & 44 & 100 \\
\hline Counsellor & 17 & 60,71 & 11 & 39,29 & 28 & 100 \\
\hline $\begin{array}{c}\text { Minister } \\
\text { Consellor }\end{array}$ & 8 & 61,54 & 5 & 38,46 & 13 & 100 \\
\hline Minister & 161 & 63,14 & 94 & 36,86 & 255 & 100 \\
\hline Total & & & & & &
\end{tabular}

Source: Data anlyzed, 2019

For the criteria of respondents used as research subjects according to educational level can be seen in the following table:

\begin{tabular}{ccccccccc}
\hline \multirow{2}{*}{$\begin{array}{l}\text { Diplomatic } \\
\text { Rank }\end{array}$} & S-1 & $\%$ & S-2 & $\%$ & S-3 & $\%$ & Total & $\%$ \\
\cline { 2 - 7 } & 32 & 0 & 0 & 0 & 0 & 0 & 32 & 100 \\
\hline Attache & 31 & 0 & 0 & 0 & 0 & 0 & 31 & 100 \\
\hline Secretary III & 70 & 92,11 & 6 & 7,89 & 0 & 0 & 76 & 100 \\
\hline Secretary II & 27 & 87,09 & 4 & 12,91 & 0 & 0 & 31 & 100 \\
\hline Secretary I & 9 & 20,45 & 33 & 75 & 2 & 4,55 & 44 & 100 \\
\hline Counsellor & 7 & 25 & 18 & 64,29 & 3 & 10,71 & 28 & 100 \\
\hline $\begin{array}{c}\text { Minister } \\
\text { Consellor }\end{array}$ & 0 & 0 & 13 & 0 & 0 & 0 & 13 & 100 \\
\hline Minister & 0 & 69,02 & 74 & 29,02 & 5 & 1,96 & 255 & \\
\hline Total & 176 & 69 &
\end{tabular}

\section{Measurement Model (Outer Model)}

Outer evaluation of model indicators in this study is conducted through two stages, namely evaluation on the first order construct, that is the construct formed by the indicators and evaluation on the second order construct, that is the construct formed by first order construct which is to be its dimension. Following is the picture of the first order:

\section{First Order Construct}


P-value of the PLS Warp output is used to test the relationship between variables (hypothesis testing), the. The following is the table that gives the results of influence between constructs (variables):

\begin{tabular}{clccc}
\hline Hypothesis & \multicolumn{1}{c}{ Construct } & $\begin{array}{l}\text { Koef. } \\
\text { Path }\end{array}$ & P Value & Notes \\
\hline $\mathrm{H}_{1}$ & Effect of TL on IC & 0.889 & $<0.001$ & Significant*** \\
\hline $\mathrm{H}_{2}$ & Effect of TL on CD & 0.35 & $<0.001$ & Significant $* * *$ \\
\hline $\mathrm{H}_{3}$ & $\begin{array}{l}\text { Effect of TL on OC through } \\
\mathrm{CD}\end{array}$ & 0.205 & $<0.001$ & Significant $* * *$ \\
\hline $\mathrm{H}_{4}$ & $\begin{array}{l}\text { Effect of IC on OC through } \\
\mathrm{CD}\end{array}$ & 0.004 & 0.46 & not Significant \\
\hline
\end{tabular}

\section{$\mathrm{H}_{1}$ : Transformational Leadership has a positive and significant effect on Interpersonal Communication}

Based on hypothesis testing reveals that the path parameter coefficient of the influence of Transformational Leadership (X1) on Interpersonal Communication (X2) is 0.889 at the significance level $\alpha=0,000<0.05$, indicating that there is a significant positive influence between Transformational Leadership (X1) ) towards Interpersonal Communication (X2). This finding indicates that the better transformational leadership in hierarchical level then interpersonal communication of diplomats at the Ministry of Foreign Affairs Republic of Indonesia will get more increased.

Some research results regarding the relationship of Transformational Leadership to Interpersonal Communication that support the results of this study, among others are conducted by Qader Vazifeh Damirch, Gholamreza Rahimi and, Mir Hosein Seyyedi (2011: 125) in which their research results reveal that transformational leadership influences innovative behavior and innovative climate. In this context, innovative behavior is defined as the ability of transformative leaders to motivate and change the mindset of employees or subordinates through effective communication processes for organizational sustainability, while innovative climate is the ability of transformative leaders to create a conducive work environment to be able to present an interactive and harmonious working relationship in an organization. the effort to create a harmonious work environment through leaders' interpersonal communication skills.

Another research result conducted by Patrick Adigwe and Ephraim Okoro (2016: 1) with the research title "Human Communication and Effective Interpersonal Relationships: An Analysis of Client Counseling and Emotional Stability." Their finding showed that interpersonal communication was significantly positively related to personal satisfaction, emotional stability, effectiveness of interactions and organizational commitment. It was explained that selfsatisfaction is the reception of messages in accordance with self-worth or self-concept (selfconcept); emotional stability is the balance of the heart and mind (heart and mind) in response to receiving messages; while the effectiveness of the interaction is the sender and recipient of information has the same view or meaning of a concept or message so that there is mutual understanding between the two (the sender and receiver of the message).

Reeta Raina and Deborah Britt Roebuck (2016: 1) also examined the relationship of effective communication to job satisfaction and organizational commitment. The results of his research revealed that effective communication has a positive and significant influence on job satisfaction and organizational commitment. It was explained that the leader must be able to create a conducive environment by conveying clear messages, precise instructions and on time.

Then George BUCĂȚA and Alexandru Marius RIZESCU (2016; 57-58) conducted a literature review on the relationship between leaders and communication where their research results showed that the communication process in an essential media company in the management system. Communication as management functions as a facilitator of relationships 
between people to form a conducive internal work environment. Thus managers or communication skills are the priorities of leaders or managers, communication is a fundamental skill to achieve the desired goals of the organization.

\section{$\mathrm{H}_{2}$ : Transformational Leadership has a positive and significant effect on Career Development}

Based on the hypothesis testing above reveals that the path parameter coefficient from the influence of Transformational Leadership (X1) on Career Development (X3) is 0.35 at a significance level of $\alpha=0,000<0.05$, indicating that there is a significant positive influence between Transformational Leadership (X1) towards Career Development (X3). This finding indicates that the better transformational leadership in hierarchical level can give positive contribution to career development of diplomats in the Ministry of Foreign Affairs Republic of Indonesia.

This research finding is supported by the theory put forward by Bass et al., $(2006 ; 142)$ that there are three ways transformational leadership supports employee career development in an organization. First, transformational leadership which can show itself as a role model to be emulated by subordinates. In this context, transformative leaders provide examples of good attitude and behavior in accordance with organizational values. Second, transformative leaders always provide motivation and inspiration to subordinates to achieve better performance, both soft performance, such as loyalty, discipline, commitment, satisfaction, cooperation and hard performance, such as achievement on target and productivity. Third, organizational culture has a strategic role to support employee career development. In addition, organizational culture also has a role in running and maintaining employee career paths.

Hussein N. Ismail Mayssa Rishani's research result $(2018 ; 111)$ also shows that transformative leaders can influence career development of employees. It was explained that in addition to being a leader as a role model, motivation and organizational culture, a performance evaluation system (PAS) can also influence career development as explained by an organization that has a clear career path will increase employee creativity and simultaneously performance assessment systems have an impact on employee career development. Employees who are satisfied with the performance appraisal system (e.g. due to the existence of honesty, fairness and support for performance) can cause positive impressions of employees towards career development.

Research finding conducted by Mehmet Sahin G and Büşra K. (2016: 1) also reveals that leadership behavior (transformational leadership) influences career development. It is further explained that, managerial levels and skills, efficient leadership, reflections of leadership and leadership theories in terms of the current entities affect job satisfaction and organizational commitment directly. job satisfaction means that as long as individuals are happy and peaceful in their job, the positive feeling they have towards their job increases.

\section{$\mathrm{H}_{3}$ : Transformational Leadership has a positive and significant effect on Organizational Commitment through Career Development}

Pathway coefficient for the influence of Transformational Leadership (X1) on Organizational Commitment (Y) through Career Development (X3) is 0.205 at the significance level $\alpha=0.000<0.05$, indicating that there is a significant positive influence between Transformational Leadership (X1) on Commitment Organization (Y) through Career Development (X3). This finding indicates that the better transformational leadership in hierarchical level can influence career development and have an impact on increasing organizational commitment of diplomats in the Ministry of Foreign Affairs Republic of Indonesia.

The finding of this study is supported by several relevant studies, including research conducted by Chun-Fang Chiang and Yi-Ying Wang (2012: 9). Their research result indicates that transformational leadership has a significant positive effect on continuance commitment mediated by cognitive trust (cognitive trust). In the conclusion explained that transformative leadership has an important role to form cognitive trust in employees.

Furthermore, according to Podsakoff et al. quoted by Chun-Fang Chiang and Yi-Ying Wang (2012: 1) that transformational leadership is able to shape employees' trust in their leaders. Therefore, trust is the mediating variable between transformational leadership and organizational citizenship behavior. 
Transformational leadership is a conscious process that influences individuals or groups with the aim of creating sustainable organizational change. Transformational leadership transforms organizations through strengthening others by providing role-model (exemplary). Transformational leadership unites belief (trust) and form positive feelings, has a value and a strong effort to achieve the desired goals. In addition, transformational leadership encourages others to resolve problems from new perspective, provides support and courage, conveys a clear vision.

\section{$\mathrm{H}_{4}$ : Effect of Interpersonal Communication on Organizational Commitment through Career Development}

Pathway coefficient for the influence of Interpersonal Communication (X2) on Organizational Commitment (Y) through Career Development (X3) is 0.004 at the significance level $\alpha=0.46>0.05$, indicating that there is a positive but not significant effect between Interpersonal Communication (X2) towards Organizational Commitment (Y) through Career Development (X3). This path parameter values indicates that good interpersonal communication neither affect career development nor has an impact on the organizational commitment of diplomats at the Ministry of Foreign Affairs of the Republic of Indonesia.

\section{CONCLUSION AND RECOMMENDATION}

\section{Conclusion}

1.Transformational leadership has a positive and significant effect on interpersonal communication which shows that the better transformational leadership in all levels, then interpersonal communication of diplomats will get more increased in the Ministry of Foreign Affairs of the Republic of Indonesia.

2. Transformational leadership has a positive and significant influence on Career Development which indicates that the better the transformational leadership in all levels can provide positive effect on career development of diplomats in the Ministry of Foreign Affairs of the Republic of Indonesia.

3. Transformational Leadership has a positive and significant effect on Organizational Commitment through Career Development which reveals that the better transformational leadership in all levels can influence career development and give impact on organizational commitment of diplomats at the Ministry of Foreign Affairs of the Republic of Indonesia.

4. Interpersonal communication has a positive effect on career development but does not have impact on the organizational commitment of diplomats at the Ministry of Foreign Affairs of the Republic of Indonesia.

\section{Recommendation}

1. The transformational leadership model at all levels needs to be continuously developed and implemented because it has a positive effect on interpersonal communication, career development and the organizational commitment of diplomats at the Ministry of Foreign Affairs of the Republic of Indonesia.

2. Interpersonal communication still needs to be developed in such a way to have a positive influence on the organizational commitment of diplomats to the Ministry of Foreign Affairs of the Republic of Indonesia.

\section{REFERENCES}

Abouraia, Mahmoud Kamal and Saad Mohammed Othman. (2017). Transformational Leadership, Job Satisfaction, Organizational Commitment, and Turnover Intentions: The Direct Effects among Bank Representatives. American Journal of Industrial and Business Management. https://doi.org/10.4236/ajibm.2017.74029

Adigwe, Patrick and Ephraim Okoro. (2016). Human Communication and Effective Interpersonal Relationships: An Analysis of Client Counseling and Emotional Stability. International Journal of Economics \& Management Sciences. http://dx.doi.org/10.4172/2162-6359.1000336 
Boe, Ole and Torill Holth (2017) Is Guidance as a Tool for Leadership Communication Effective for Military Leaders? Arts and Social Sciences Journal. DOI: 10.4172/21516200.1000263

Bucăţa, George dan Alexandru Marius Rizescu (2017). The Role of Communication in Enhacing Work Effectiveness of an Organizaiton. Manajemen and Economics. george.bucata@yahoo.ro and mariusrizescu@yahoo.com

Bungin, Burhan. (2005). Metodologi Penelitian Kuantitatif, edisi kedua. Jakarta: Kencana.

Chun-Fang Chiang, and Yi-Ying Wang (2012).The Effects of Transactional and Transformational Leadership on Organizational Commitment in Hotels: The Mediating Effect of Trust. Journal of Hotel \& Business Management. DOI: 10.4172/21690286.1000103

Dabke, Deepika. (2016). Impact of Leader's Emotional Intelligence and Transformational Behavior on Perceived Leadership Effectiveness: A Multiple Source View. 29. Business Perspectives and Research. DOI: 10.1177/2278533715605433

Damirch, Qader Vazifeh, Gholamreza Rahimi, dan Mir Hosein Seyyedi. (2011). Transformational Leadership Style And Innovative Behavior On Innovative Climate At Smes In Iran. Arabian Journal of Business and Management Review, Vol. 1, No.4; December 2011

Dingxiang Chen and Xiaobao Peng. (2017). Research on the Relationship between Transformational Leadership and Government Service Innovation. Open Journal of Leadership. http://www.scirp.org/journal/ojl

G, Mehmet Sahin and Büşra K (2016) Effects of Leadership Behavior on the Organizational Commitment and Job Satisfaction: A Public Sector Research. Journal of Entrepreneurship \& Organization Management. DOI: 10.4172/2169-026X.1000184

G, Sabghatullah. (2018) Successful Intercultural Communication in Local Organization. Journal of Tourism \& Hospitality. DOI: 10.4172/2167-0269.1000386

HA, Gabbar Honarmand N, and Abdelsalam AA. (2014). Transformational Leadership and its Impact on Governance and Development in African Nations: An Analytical Approach. Journal of Entrepreneurship \& Organization Management. DOI: 10.4172/2169-026X.1000121

Hamstra, Melvyn R. W. Nico W., Van Yperen, Barbara Wisse, dan Kai Sassenberg. (2014). Transformational and Transactional Leadership and Followers' Achievement Goals. $J$ Bus Psychol. DOI 10.1007/s10869-013-9322-9

Miroshnik, Victoria. (2013). Organizational Culture and Commitment. London: Palgrave Macmillan.

Nazir, Moh.. (2009). Metode Penelitian. Bogor: Ghalia Indonesia.

Peraturan Menteri Luar Negeri Republi Indonesia Nomor 4 tahun 2009 tentang Pejabat Dinas Luar Negeri, Diplomatik dan konsuler

Pradhan, Sajeet dan Rabindra Kumar Pradhan. (2015). An Empirical Investigation of Relationship among Transformational Leadership, Affective Organizational Commitment and Contextual Performance. Vision. 1. DOI: 10.1177/0972262915597089

Raina, Reeta and Deborah Britt Roebuck. (2016) Exploring Cultural Influence on Managerial Communication in Relationship to Job Satisfaction, Organizational Commitment, and the Employees' Propensity to Leave in the Insurance Sector of India. International Journal of Business Communication. 98. DOI: 10.1177/2329488414525453

Rencana Strategis Kementerian Luar Negeri tahun 2015 - 2019

Rishani, Hussein N. Ismail Mayssa. (2018). The Relationship Among Performance Appraisal Satisfaction, Career Development and Creative Behavior, Journal of Developing Areas, Vol. 52, No. 3,

Sugiyono. (2009). Metode Penelitian Kuantitatif, Kualitatif dan $R \&$ D. Bandung: Alfabeta,

Suharsaputra. Uhar. (2014) .Metode Penelitian, Kuantitatif, Kualitatif dan Tindakan. Bandung: Aditama.

Torrington, Derek, Laura Hall, dan Stephen Taylor. (2005). Human Resource Management, sixt edition. England: Prentice Hall.

Torrington, Derek, Laura Hall, Stephen Taylor, and Carol Atkinson. (2014). Human Resource Management, $9^{\text {th }}$ edition. United Kingdom: Pearson.

Vatankhah, Soudabeh, Samira Alirezaei, Omid Khosravizadeh, Seyyed Elmira Mirbahaeddin, MahtabnAlikhani, Mobarakeh Alipanah. (2017). Role Of Transformational Leadership 
On Employee Productivity Of Teaching Hospitals: Using Structural Equation Modeling. Electronic Physician. 4979. DOI: http://dx.doi.org/10.19082/4978

Wati, Lela Nurlaela. (2018). Metodologi Penelitian Terapan. Jakarta: Pustaka Amri

Ying Ao. (2016). The Impact of Cross-Cultural Communication on Foreign Managers' Leadership Style in China-Based International Organization. Open Journal of Social Sciences. http://dx.doi.org/10.4236/jss.2016.49010 